\title{
Fabrication and Applications of Metal-Ion-Doped Hydroxyapatite Nanoparticles
}

\author{
Yan $\mathrm{Li}^{1,2 *}$, Dandan Wang ${ }^{1,2}$ and Sierin $\mathrm{Lim}^{3}$ \\ ${ }^{1}$ Department of Biomedical Engineering, Sun Yat-sen University, Guangzhou, China \\ ${ }^{2}$ Department of Provincial Engineering and Technology, Sun Yat-sen University, China \\ ${ }^{3}$ Department of Chemical and Biomedical Engineering, Nanyang Technological University, Singapore
}

Submission: April 04, 2017; Published: May 04, 2017

*Corresponding author: Yan Li, Department of Biomedical Engineering, Sun Yat-sen University, Guangzhou, China, Tel: +86-20-39387890;

Fax: +86-20-39387890; Email: liyan99@mail.sysu.edu.cn

\begin{abstract}
Calcium hydroxyapatite (HAp) is the main inorganic component of natural bones. In this review, the crystal structure and fabrication methods of HAp were first introduced; then the synthesis and applications of metal-ion-doped HAp nanoparticles were mainly reviewed. HAp was usually synthesized through solid state reaction and wet chemical precipitation, of which the properties depended on the fabrication method. Due to its crystal structure, HAp can tolerate ion-exchange with a high amount of other ions without significantly affecting its lattice structure. Hence ion-exchange reaction of $\mathrm{HAp}$ has been used to remove heavy metal ions such as $\mathrm{Pb}^{2+}$ or $\mathrm{Cd}^{2+}$ in waste water or soils, and immobilize radioactive waste. The adsorption capacity depended on the crystallinity and specific surface area of HAp. Meanwhile other metal ions besides Ca can be introduced into HAp through ion exchange or co precipitation method to form metal ion doped HAp. Due to the presence of these metal ions, the properties of HAp were either enhanced or new properties were introduced. The electrical conductivity and catalysis effect of HAp were increased due to ion substitution; the metal ion doped HAp demonstrated potential for better performance in tissue engineering, can be paramagnetic or used as fluorescence probes. The applications of HAp were thus broadened.
\end{abstract}

Keywords: Hydroxyapatite; Ion-exchange; Catalysis; anti-bacterial; Magnetic; Biomedical applications

Abbreviations: HAp: Hydroxyapatite; FTIR: Fourier Transform Infrared Spectroscopy; SSA: Specific Surface Area; TiHAp: Ti ${ }^{4+}$ Doped Hap

\section{Introduction}

Calcium hydroxyapatite, $\mathrm{Ca}_{10}\left(\mathrm{PO}_{4}\right)_{6}(\mathrm{OH})_{2}$, is usually referred as hydroxyapatite (HAp). The carbonated HAp doped with other ions is the major inorganic component of hard tissues, such as bones and teeth. Because of its osteoconductivity and biocompatibility., HAp is widely used for low-load bearing applications or as a coating material for metallic implants.

HAp can tolerate a high ion substitution without changing its lattice structure. Recently, much attention has been paid to the ions substituted HAp in order to modify its properties and also broaden the applications. Fluorine substitution increased the electrical conductivity of porous $\mathrm{HAp}[1] . \mathrm{Cu}^{2+}, \mathrm{Ni}^{2+}$ and $\mathrm{Co}^{2+}$ substituted HAp had catalytic effect for specific reactions $[2,3] . \mathrm{Ag}^{+}$substituted HAp showed antibacterial effect [4] and $\mathrm{Ti}^{4+}$ substituted HAp can be used as a photo catalyst $[5,6] . \mathrm{Eu}^{3+}$ and $\mathrm{Tb}^{3+}$ doped HAp have applications as fluorescent probes [7].
In addition, HAp has been used as a drug carrier in various systems [8-10]. The size of HAp is usually in nanometers range with high surface area when produced using wet chemical method [11]. Both hydrophilic [12] and hydrophobic [9] drugs can be adsorbed onto the HAp surface. However, the drug release profile was hard to control [13]. The drug release profile of HAp particulate system usually had a high initial burst and a short release time range [9]. In order to prolong the drug release time, porous HAp blocks or granules have been used with drugs impregnated into the pores $[10,14]$. The main disadvantage of these blocks or granules delivery systems was that they were so large and can only be implanted in particular tissues. Thus, composites microparticles, consisting of HAp and polymer overcame these drawbacks $[15,16]$.

\section{Crystal structure and synthesis of HAp}

HAp has two kinds of unit cells, hexagonal and monoclinic. Only the stoichiometric HAp possesses monoclinic structure with space group P21/b and lattice parameters a $=9.426(3)$ 
$\AA, \mathrm{b}=18.856(5) \AA, c=6.887(1) \AA ̊, \gamma=119.97(1)^{\circ}$ [17]. Most synthetic HAp is hexagonal with space group $\mathrm{P}_{3} / \mathrm{m}$ and lattice parameters $\mathrm{a}=9.424(4) \AA, \mathrm{b}=2 \mathrm{a}, \mathrm{c}=6.879(4) \AA$ and $\gamma$ $=120^{\circ}$ [18]. In the hexagonal structure, the regular phosphate tetrahedra compose the matrix of the crystal (Figure 1). There are two nonequivalent sites for calcium, $\mathrm{Ca}(\mathrm{I})$ and $\mathrm{Ca}(\mathrm{II})$. For the $\mathrm{Ca}(\mathrm{I})$ atoms, each is along the threefold axes and bonded to six oxygen atoms at an essentially equal distance, which form a twisted triangular prism. There is also bonding between these $\mathrm{Ca}(\mathrm{I})$ atoms and three $\mathrm{O}$ atoms at a longer distance. Thus the $\mathrm{Ca}(\mathrm{I})$ atoms are coordinated by nine $\mathrm{O}$ atoms located in six different phosphate tetrahedra. The Ca (II) atoms situated around the hexagonal screw axes, each have an irregular seven fold coordination with six $\mathrm{O}$ atoms from five phosphate groups along with the hydroxyl ion [19]. The $\mathrm{OH}$ columns are parallel to $c$ axis and the main lines of the columns pass through the centers of Ca triangles which are on the mirror plane at $\mathrm{z}=1 / 4$ and $z=3 / 4$. The monoclinic HAp exhibits structural similarity to the hexagonal HAp [17]. The greatest difference between monoclinic and hexagonal HAp is the arrangement of the hydroxyl ions. In the monoclinic structure, HAp is pure enough that the $\mathrm{OH}$ columns are arranged in an ordered manner, where all the $\mathrm{OH}$ ions are displaced in the same direction from $\mathrm{z}=1 / 4$. Furthermore, all the $\mathrm{OH}$ columns point in the same direction within a plane parallel to a and $\mathrm{c}$ axes, but the direction of the displacements alternated between adjacent planes. This ordered arrangement of $\mathrm{OH}$ ions in the monoclinic structure changes the mirror planes in $\mathrm{P}_{3} / \mathrm{m}$ into b glide planes in $\mathrm{P} 2_{1} / \mathrm{b}$ and double the $\mathrm{b}$ axis parameter.

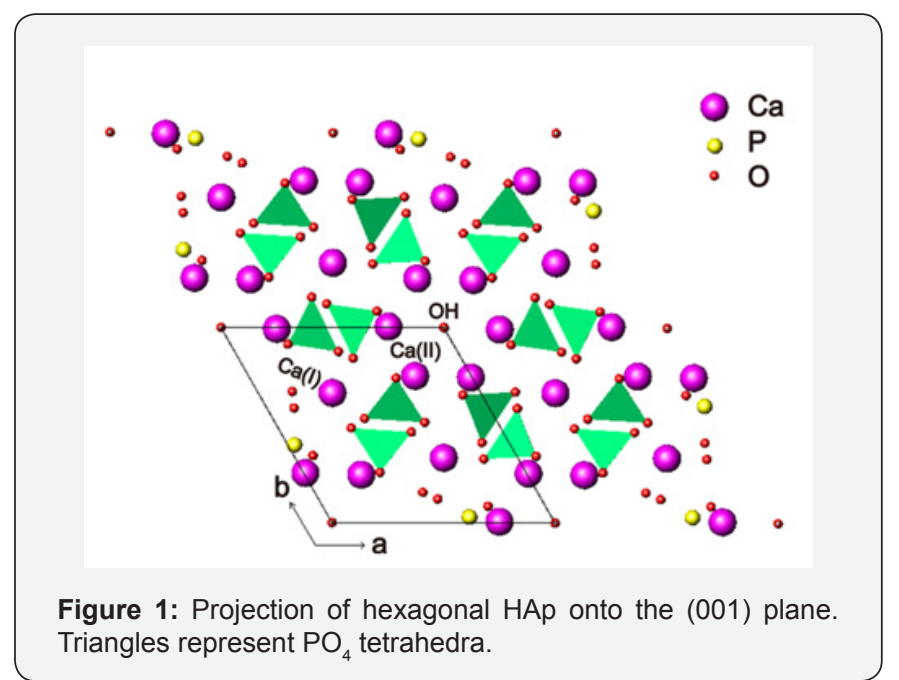

HAp has quite high tolerance for ion substitution due to its special structure. $\mathrm{OH}$ - ions can be replaced by $\mathrm{F}$ - and $\mathrm{Cl}$ ions; while $\mathrm{PO}_{4}{ }^{3-}$ ions can also be substituted with $\mathrm{CO}_{3}{ }^{2-}$ and $\mathrm{SiO}_{4}{ }^{4-}$ ions. The most interesting is the metal ions taking the positions of calcium in HAp lattice without changing the structure. With the incorporation of metal ions, the properties of HAp can also be modified.
To synthesize HAp, there are two major routes: solid state reaction and wet chemical methods [20]. Solid state reaction is mixing stoichiometric quantity of calcium precursor (such as $\left.\mathrm{CaCO}_{3}\right)$ and phosphorus precursor $\left(\mathrm{CaHPO}_{4} \cdot 2 \mathrm{H}_{2} \mathrm{O}\right.$ or $\left.\mathrm{Ca}_{2} \mathrm{P}_{2} \mathrm{O}_{7}\right)$, followed by preheat treatment and shaping into disks and eventually reacted at $\sim 1000^{\circ} \mathrm{C}$ [21]. It usually produces stoichiometric and well crystallized HAp. However, a relatively high temperature and long heat treatment is needed and the sinterability of the product is low. For wet chemical methods, the reaction takes place in aqueous media. The crystallinity and $\mathrm{Ca} / \mathrm{P}$ ratio depend strongly on the preparation conditions. Wet methods include precipitation, hydrothermal technique and hydrolysis of other calcium phosphates. Among these methods, the precipitation method usually gives nanocrystalline HAp and the shape of the nanoparticles can be controlled, either in needles or spheroids [11]. Nanometer-sized HAp has been reported to have better bioactivity than the micrometer-sized HAp [22].

The two most popular ways of precipitating HAp are shown in Eqs 1 and 2. The reactions usually involve adding phosphorous precursor slowly into calcium precursor and/or adjusting the reaction $\mathrm{pH}$ using ammonia $[20,23,24]$. Eq 1 is the reaction between calcium hydroxide and or tho-phosphoric acid $[11,25]$, and Eq 2 is the reaction between calcium nitrate and ammonium dihydrogen phosphate with ammonium hydroxide to maintain the $\mathrm{pH}$ value of the reaction solution [20]. During the precipitation process, $\mathrm{CO}_{3}{ }^{2-}$ groups were easily introduced into HAp lattice. This was probably due to the presence of $\mathrm{CaCO}_{3}$ in the reactants and dissolved $\mathrm{CO}_{2}$ from atmosphere. If $\mathrm{CO}_{3}{ }^{2-}$ groups replace $\mathrm{OH}-$, it is referred to as A-type carbonated $\mathrm{HAp}$ and if $\mathrm{CO}_{3}{ }^{2-}$ substitutes $\mathrm{PO}_{4}{ }^{3-}$, this is known as B-type carbonated HAp [11]. The different substitutions can be distinguished based on FTIR spectrum [11]. In order to prevent the presence of $\mathrm{CO}_{3}^{2-}$ groups in $\mathrm{HAp}$, some researchers have used $\mathrm{CaO}$ as the starting material which is the decomposition product of $\mathrm{CaCO}_{3}[17,25]$, while others have applied $\mathrm{CO}_{2}$ free atmosphere $\left(\mathrm{N}_{2}\right.$ or $\left.\mathrm{Ar}\right)$ during the synthesis process $[23,25]$.

$$
\begin{array}{r}
5 \mathrm{Ca}(\mathrm{OH})_{2}+3 \mathrm{H}_{3} \mathrm{PO}_{4} \rightarrow \mathrm{Ca}_{5}\left(\mathrm{PO}_{4}\right)_{3}(\mathrm{OH})+9 \mathrm{H}_{2} \mathrm{O} \\
5 \mathrm{Ca}\left(\mathrm{NO}_{3}\right)_{2}+3\left(\mathrm{NH}_{4}\right)_{2} \mathrm{HPO}_{4} \rightarrow \mathrm{Ca}_{5}\left(\mathrm{PO}_{4}\right)_{3}(\mathrm{OH})+3 \mathrm{H}_{2} \mathrm{O}+10 \mathrm{NH}_{4} \mathrm{NO}_{3}
\end{array}
$$

To synthesis HAp for biomedical applications, Eq 1 was usually used because it is a simple formulation with the advantage of water being its only byproduct. Since $\mathrm{CO}_{3}{ }^{2-}$ groups are naturally present in bones [26], the presence of $\mathrm{CO}_{3}{ }^{2-}$ groups in HAp was not expected to affect cell response.

\section{Synthesis of metal ion doped HAp nanoparticles}

To synthesize metal ions doped HAp nanoparticles, coprecipitation [5,6] and ion exchange methods [27,28] are usually used. The former is by including metal ions in calcium solution while the latter is by adding metal ion solutions after HAp nanoparticles have been formed. These two methods 
modify HAp in different manners. The coprecipitation method changes both the surface and bulk concentration of metal ions, while the ion exchange method usually results in higher concentration of metal ions on the surface of HAp nanoparticles than the bulk since ion-exchange is limited to the particles surface [28]. For HAp fabricated following Eq 1, when coprecipitation method was chosen, $\mathrm{M}(\mathrm{OH}) \mathrm{x}$ may also be precipitated as one of the byproducts due to the corresponding low solubility product of the metal hydroxide. This in turn could affect the precipitation of metal ion doped HAp. In addition, the presence of metal ions in the reaction system may affect the crystallization process of HAp and resulted in amorphous calcium phosphate nanoparticles or nanoparticles in unexpected shapes. Hence, ion-exchange method was preferred to synthesize the metal ion doped HAp even though the added metals ions were more concentrated on the surface.

\section{Applications of ion exchange reaction of HAp}

HAp has been used for the removal of heavy metal ions such as $\mathrm{Pb}^{2+}$ or $\mathrm{Cd}^{2+}$ in waste water or soils $[29,30]$, and immobilization of radioactive waste [31,32]. The adsorption capacity depends on the crystallinity and specific surface area (SSA) of HAp. HAp powder with a low crystallinity and a high SSA showed quantitative removal for a wide range of heavy metal ions ( $\mathrm{Pb}, \mathrm{Zn}, \mathrm{Be}, \mathrm{U}, \mathrm{Bi}, \mathrm{V}, \mathrm{Al}, \mathrm{Cu}$ and $\mathrm{Ga})$, while the calcined powder with a higher crystallinity and lower SSA showed a quantitative removal only for a few elements ( $\mathrm{Pb}, \mathrm{Bi}$ and $\mathrm{Ga}$ ) [29]. Studies on natural apatites from the fossil nuclear reactor of Oklo found that these compounds supported high doses of external and internal $\alpha$ irradiation with no significant changes in the crystal structure [31].

Ion removal or immobilization by HAp takes place through two mechanisms, as shown in Eqs 3-5 [29]. The first mechanism is the dissolution and precipitation theory (Eqs 3 and 4), where HAp provides phosphates by dissolution which then react with the metal ions to precipitate low soluble metal phosphate according to Eq 4. The second mechanism is the ion exchange theory (Eq 5), where metal ions adsorbed to the surface of HAp particles to replace $\mathrm{Ca}^{2+}$ ions in the lattice.

$$
\begin{aligned}
& \mathrm{Ca}_{10}\left(\mathrm{PO}_{4}\right)_{6}(\mathrm{OH})_{2}+14 \mathrm{H}^{+} \rightarrow 10 \mathrm{Ca}^{2+}+6 \mathrm{H}_{2} \mathrm{PO}_{4}^{-}+2 \mathrm{H}_{2} \mathrm{O} \\
& 10 \mathrm{Me}^{2+}+6 \mathrm{H}_{2} \mathrm{PO}_{4}^{-}+2 \mathrm{H}_{2} \mathrm{O} \rightarrow \mathrm{Me}_{10}\left(\mathrm{PO}_{4}\right)_{6}(\mathrm{OH})_{2}+14 \mathrm{H}^{+} \\
& \mathrm{Ca}_{10}\left(\mathrm{PO}_{4}\right)_{6}(\mathrm{OH})_{2}+\mathrm{xMe}^{2+} \rightarrow \mathrm{Ca}_{10-\mathrm{x}} \mathrm{Me}_{\mathrm{x}}\left(\mathrm{PO}_{4}\right)_{6}(\mathrm{OH})_{2}+\mathrm{xMe}^{2+}+\mathrm{xCa}^{2+}
\end{aligned}
$$

\section{Applications of metal ion doped HAp}

Metal ion doped HAp have been applied in many fields. HAp and metal ion doped HAp demonstrated certain catalytic properties. The partial oxidation of methane to carbon monoxide and hydrogen has been reported to be catalyzed by $\mathrm{HAp}$ at $\sim 600^{\circ} \mathrm{C}$. The formation of oxygen radical species on $\mathrm{HAp}$ has also been found [3]. Introduction of $\mathrm{Cu}^{2+}$ and $\mathrm{Ni}^{2+}$ ions into HAp matrix creates new redox centers and causes a large increase in activity of dehydrogenation of alcohols with little effect on the dehydration function of HAp [2]. HAp has also been reported to decompose compounds such as methyl mercaptane and dimethyl sulfide effectively under UV (254nm) irradiation [5]. To modify the photo catalysis effect of HAp, $\mathrm{Ti}^{4+}$ ions was introduced into HAp by coprecipitation method $[5,6,33] . \mathrm{Ti}^{4+}$ doped HAp absorbed UV light at a wavelength less than $380 \mathrm{~nm}$, so that it exhibited a much higher photo catalytic activity in oxidation and decomposition of acetaldehyde under UV irradiation than unmodified HAp [33]. As reported by $\mathrm{Hu}$ et al. [5], $\mathrm{Ti}^{4+}$ substituted HAp had photo catalytic effect both under visible light and UV irradiation and the photo catalytic activity of HAp was excited by Ti substitution. Since HAp had much higher affinity with biomaterials than $\mathrm{TiO}_{2}, \mathrm{Ti}^{4+}$ modified HAp differed from $\mathrm{TiO}_{2}$ in both adsorption affinity and photo catalytic activity for organisms. Additionally, $\mathrm{Ti}^{4+}$ doped $\mathrm{HAp}$ even showed bactericidal effect in the dark $[6,33]$.

To improve the antibacterial property, $\mathrm{Ag}^{+}, \mathrm{Cu}^{2+}$ or $\mathrm{Zn}^{2+}$ ions were co-substituted into $\mathrm{Ti}^{4+}$ doped HAp (TiHAp) [34]. TiHAp was first produced using coprecipitation method and $\mathrm{Ag}^{+}, \mathrm{Cu}^{2+}$ or $\mathrm{Zn}^{2+}$ ions were introduced by ion exchange method. $\mathrm{Ag}^{+}$, $\mathrm{Cu}^{2+}$ co-substituted TiHAp coated on porous spumous nickel film showed high efficiency in killing E. coli and S. aureus in the dark and under weak UV irradiation. It was found that oxygen radical formed on $\mathrm{Ag}^{+}, \mathrm{Cu}^{2+}$ co-substituted $\mathrm{TiHAp}$ at ambient temperatures. Antibacterial effect of $\mathrm{Ag}^{+}, \mathrm{Cu}^{2+}$ or $\mathrm{Zn}^{2+}$ substituted HAp synthesized using coprecipitation method was also investigated [4]. Kim et al. [4] reported that $\mathrm{Ag}^{+}$doped HAp showed a high antimicrobial property while $\mathrm{Cu}^{2+}$ and $\mathrm{Zn}^{2+}$ in HAp did not show any antimicrobial property against E. coli. The strong bactericidal effect of $\mathrm{Ag}^{+}$and non-antibacterial effect of $\mathrm{Zn}^{2+}$ in HAp against $E$. coli was similarly reported by $\mathrm{Hu}$ et al. [34]. While Kim et al. observed that $\mathrm{Cu}^{2+}$ substituted HAp synthesized using coprecipitation method did not show any antimicrobial property against E. coli [4]; Hu etal. [34] noted that $\mathrm{Cu}^{2+}$ co-substituted TiHAp was found to kill E. coli and S. aureus effectively [34]. Another paper on $\mathrm{Cu}^{2+}$ doped HAp produced by ion exchange method, had a high antibacterial activity on E. coli [35], which was similar with Hu's results [34]. The different observations on the antibacterial effect of $\mathrm{Cu}^{2+}$ doped HAp was possibly due to the different ways of introducing $\mathrm{Cu}^{2+}$ ions into HAp, which further resulted in different concentration distribution of $\mathrm{Cu}^{2+}$ ions in HAp nanoparticles. Introduction of $\mathrm{Cu}^{2+}$ ions into HAp by coprecipitation did not show bacterial effect while introduction of $\mathrm{Cu}^{2+}$ ions by ion exchange method demonstrated high antibacterial property. The coprecipitation method changed both the surface and bulk concentration of metal ions; while the ion exchange method usually gives rise to higher concentration of metal ions on the surface of HAp nanoparticles than the bulk since ion-exchange process was limited to the surface [28]. 
Biological HAp crystals contain lots of other ions, such as $\mathrm{K}^{+}, \mathrm{Mg}^{2+}, \mathrm{Na}^{+}, \mathrm{CO}_{3}{ }^{2-}$ and $\mathrm{F}-$, to name a few [36]. As the carbonate content in enamel may be related with the susceptibility to dental caries [37], $\mathrm{Na}^{+}$and $\mathrm{CO}_{3}{ }^{2-}$ co-substituted HAp was fabricated and the structure was refined using Rietveld refinement [37]. $\mathrm{La}^{3+}$ and $\mathrm{Al}^{3+}$ doped HAp were also studied $[27,38]$ because of the inhibitory effect of $\mathrm{La}^{3+}$ and $\mathrm{Al}^{3+}$ on the demineralization of dental enamel.

Bone minerals are mainly carbonated HAp with other elements such as F, Mg, Mn, Zn, Si and Sr [36]. Even these elements are in small amount, they are fundamental to bone metabolism. $\mathrm{Zn}$ is an essential element for human health and also important for bone metabolism [37]. The slow release of $\mathrm{Zn}$ ions from implants was also reported to facilitate the formation of bone around implants and thus accelerate the healing of bone fracture and bone defects [38]. Since $\mathrm{Mn}^{2+}$ ions increased the ligand binding affinity of integrin and activate cell adhesion [26], $\mathrm{Mn}^{2+}$ doped HAp was synthesized and investigated $[26,39]$. It was found that the growth of osteo blast cells on Ti coated with $\mathrm{Mn}^{2+}$ doped HAp was enhanced as compared to uncoated Ti [26]. As compared to pure HAp, more osteoblast cells grew on Mn2+ doped HAp [40].

Rare earth metal ions doped HAp have the potential to be used as luminescence and laser material. As reported by ChaneChing et al. [41], $\mathrm{Eu}^{3+}$ and $\mathrm{Tb}^{3+}$ doped HAp nano rods displayed green and red emission peaks under excitation in the visible spectrum. These nano rods with surface bonded amino ethyl phosphate groups were individualized and stable in aqueous dispersion at neutral $\mathrm{pH}$ without aggregation or precipitation. These results allowed the application of $\mathrm{Eu}^{3+}$ and $\mathrm{Tb}^{3+}$ doped HAp as fluorescence probes in biological fields.

Magnetic property of HAp can be modified by introducing other metal ions. $\mathrm{Co}^{2+}$ doped HAp [3] and $\mathrm{Gd}^{3+}$ doped HAp [42] produced by ion exchange method was paramagnetic. For $\mathrm{Fe}^{2+}$ doped HAp, different results were obtained. Nakahira et al. [43] reported that $\mathrm{Fe}^{2+}$ doped HAp synthesized using ion exchange method was paramagnetic, while $\mathrm{Wu}$ et al. [44] produced $\mathrm{Fe}^{2+}$ doped HAp using coprecipitation method and found it was super paramagnetic. In the case of $\mathrm{Fe}^{3+}$ substituted HAp, it was found to be paramagnetic [45].

\section{Conclusion}

HAp has two kinds of lattice structures, hexagonal and monoclinic. The greatest difference between these two structures is the arrangement of the hydroxyl ions. Only the stoichiometric HAp possesses monoclinic unit cells. HAp has quite high tolerance for ion substitution, where $\mathrm{OH}^{-}$, $\mathrm{PO}_{4}{ }^{3-}$ and $\mathrm{Ca}^{2+}$ ions can be substituted without changing the structure. When using wet chemical methods to synthesize $\mathrm{HAp}$, the crystallinity and $\mathrm{Ca} / \mathrm{P}$ ratio depends strongly on the preparation conditions. In order to fabricate metal ion doped HAp, coprecipitation and ion exchange methods are usually used, which modified HAp in different manners. Compared with the coprecipitation method, ion-exchange is more limited to the particles surface. HAp has been used for the removal of heavy metal ions and immobilization of radioactive waste. For such applications, the adsorption capacity of HAp powder with a low crystallinity and a high SSA was significantly higher than the calcined powder. HAp was also reported to catalyze the decomposition of compounds such as methane, of which the catalytic effect was increased after introduction of $\mathrm{Cu}^{2+}$ and $\mathrm{Ni}^{2+}$ ions. For the applications in biomedical fields, $\mathrm{Ag}^{+}$and $\mathrm{Cu}^{+}$doped HAp showed antibacterial property; $\mathrm{La}^{3+}$ and $\mathrm{Al}^{3+}$ ions were introduced into HAp because of the inhibitory effect on the demineralization of dental enamel; $\mathrm{Zn}^{2+}$ and $\mathrm{Mn}^{2+}$ doped HAp demonstrated the potential for better performance for tissue engineering applications. Furthermore, $\mathrm{Eu}^{3+}$ and $\mathrm{Tb}^{3+}$ doped HAp can be used as fluorescence probes and magnetic properties of HAp can be modified by introducing $\mathrm{Fe}^{3+}$ and $\mathrm{Gd}^{3+}$ ions. However, limited by the low saturation magnetization values, these nanoparticles were not suitable for applications such as MRI contrast agent. By introducing other metal ions than calcium, the applications of HAp were significantly broadened.

\section{Acknowledgement}

This work was supported in part by National Natural Science Foundation of China (51303216).

\section{Conflict of Interest}

There is no any economic interest or any conflict of interest exists.

\section{References}

1. HL El, Laghzizil A, Barboux P, Saoiabi A, Lahlil K (2004) Crystallinity and fluorine substitution effects on the proton conductivity of porous hydroxyapatite. J Solid State Chem 177(1): 134-138.

2. Misono M, WK Hall (1973) Oxidation-reduction properties of copperand nickel-substituted hydroxyapatite. The journal of physical chemistry 77(6): 791-800.

3. Elkabouss K, Kacimi M, Ziyad M, Ammar S, Bozon-Verduraz F (2004) Cobalt-exchanged hydroxyapatite catalysts: Magnetic studies, spectroscopic investigations, performance in 2-butanol and ethane oxidative dehydrogenations. J Catal 226:16.

4. Kim TN, Feng QL, Kim JO, Wu J, Wang H, et al. (1998) Antimicrobial effects of metal ions $(\mathrm{Ag}+, \mathrm{Cu} 2+, \mathrm{Zn} 2+)$ in hydroxyapatite. J Mater Sci Mater Med 9(3): 129-134.

5. Hu A, Li M, Chang C, Miao D (2007) Preparation and characterization of a titanium-substituted hydroxyapatite photo catalyst. J Mol Catal A Chem 267: 79.

6. Wakamura M (2005) Photocatalysis by calcium hydroxyapatite modified with Ti (IV). Fujitsu Scientific \& Technical Journal 41: 181.

7. Lebugle A, Pelle F, Charvillat C, Rousselot I, Chane-Ching JY (2006) Colloidal and mono crystalline $\mathrm{Ln}^{3+}$ doped apatite calcium phosphate as biocompatible fluorescent probes. Chem Commun 606.

8. Queiroz AC, Santos JD, Monteiro FJ, Gibson IR, Knowles JC (2001) Adsorption and release studies of sodium ampicillin from hydroxyapatite and glass-reinforced hydroxyapatite composites. Biomaterials 22(11): 1393-1400. 
9. Mizushima Y, Ikoma T, Tanaka J, Hoshi K, Ishihara T, et al. (2006) Injectable porous hydroxyapatite microparticles as a new carrier for protein and lipophilic drugs. J Control Release 110(2): 260-265.

10. Slosarczyk A, Szymura-Oleksiak J, Mycek B (2000) The kinetics of pentoxifylline release from drug-loaded hydroxyapatite implants. Biomaterials 21(5): 1215-1221.

11. Kumar R, Prakash KH, Cheang P, Khor KA (2004) Temperature driven morphological changes of chemically precipitated hydroxyapatite nanoparticles. Langmuir 20(13): 5196-5200.

12. Sivakumar M, Rao KP (2002) Preparation, characterization and in vitro release of gentamicin from coralline hydroxyapatite-gelatin composite microspheres. Biomaterials 23(15):3175-3181.

13. Wang Y, Wang X, Wei K, Zhao N, Zhang S, et al. (2007) Fabrication, characterization and long-term in vitro release of hydrophilic drug using PHBV/HA composite microspheres. Materials Letters 61: 1071.

14. Rauschmanna MA, Wichelhausb TA, Stirnalc V, Dingeldeinc E, Zichnera L, et al. (2005) Nano crystalline hydroxyapatite and calcium sulphate as biodegradable composite carrier material for local delivery of antibiotics in bone infections. Biomaterials 26(15): 2677-2684.

15. Li Y, Lim S, Ooi CP (2012) Fabrication of Cisplatin-Loaded Poly(lactideco-glycolide) Composite Microspheres for Osteosarcoma Treatment. Pharm Res 29(3): 756-769.

16. Lin Y, Li Y, Ooi CP (2012) 5-Fluorouracil encapsulated HA/PLGA composite microspheres for cancer therapy. J Mater Sci Mater Med 23(10): 2453-2460

17. Ikoma T, Yamazaki A, Nakamura S, Akao M (1999) Preparation and structure refinement of monoclinic hydroxyapatite. J Solid State Chem 144: 272 .

18. Sudarsanan K, Young RA (1969) Significant precision in crystal structural details. Holly Springs hydroxyapatite. Acta Crystallographica Section B 25: 1534

19. Posner AS, Perloff A, Diorio AF (1958) Refinement of the hydroxyapatite structure. Acta Crystallographica 11: 308.

20. Mobasherpour I, Heshajin MS, Kazemzadeh A, Zakeri M (2007) Synthesis of nanocrystalline hydroxyapatite by using precipitation method. J Alloys Compd 430: 330.

21. Suda H, Yashima M, Kakihana M, Yoshimura M (1995) Monoclinic/ hexagonal phase-transition in hydroxyapatite studied by X-ray-powder diffraction and differential scanning calorimeter techniques. J Phys Chem 99(7): 6752-6754.

22. Zhao Y, Zhang Y, Ning F, Guo D, Xu Z (2007) Synthesis and cellular biocompatibility of two kinds of HAP with different nanocrystal morphology. J Biomed Mater Res B Appl Biomater 83(1):121-126.

23. Raynaud S, Champion E, Bernache-Assollant D, Thomas P (2002) Calcium phosphate apatites with variable $\mathrm{Ca} / \mathrm{P}$ atomic ratio I. Synthesis, characterisation and thermal stability of powders. Biomaterials 23(4) 1065-1072.

24. Afshar A, Ghorbani M, Ehsani N, Saeri MR, Sorrell CC (2003) Some important factors in the wet precipitation process of hydroxyapatite. Materials \& Design 24: 197

25. Mostafa NY (2005) Characterization, thermal stability and sintering of hydroxyapatite powders prepared by different routes. Mater Chem Phys 94(2-3): 333-341.

26. György E, Toricelli P, Socol G, Iliescu M, Mayer I, et al. (2004) Biocompatible Mn2+-doped carbonated hydroxyapatite thin films grown by pulsed laser deposition. J Biomed Mater Res A 71(2): 353358.
27. Wakamura M, Kandori K, Ishikawa T (2000) Surface structure and composition of calcium hydroxyapatites substituted with $\mathrm{Al}(\mathrm{III}), \mathrm{La}$ (III) and Fe(III) ions. Colloids Surf A 164(2-3): 297-305.

28. Wakamura M, Kandori K, Ishikawa T (1998) Surface composition of calcium hydroxyapatite modified with metal ions. Colloids Surf A 142(1): 107-116.

29. Stötzel C, Müller FA, Reinert F, Niederdraenk F, Barralet JE, et al. (2009) Ion adsorption hehaviour of hydroxyapatite with different crystallinities. Colloids Surf B Biointerfaces 74(1): 91-95.

30. Madhavi S, Ferraris C, White TJ (2005) Synthesis and crystallization of macroporous hydroxyapatite. J Solid State Chem 178(9): 2838-2845.

31. Arcos D, Rodriguez-Carvajal J, Vallet-Regi M (2005) Crystal-chemical characteristics of silicon - Neodymium substituted hydroxyapatites studied by combined X-ray and neutron powder diffraction. Chem Mater 17(1): 57-64.

32. Martin P, Carlot G, Chevarier A, Den-Auwer C, Panczer G (1999) Mechanisms involved in thermal diffusion of rare earth elements in apatite. J Nucl Mater 275: 268-276.

33. Wakamura M, Hashimoto K, Watanabe T (2003) Photocatalysis by calcium hydroxyapatite modified with Ti(IV): albumin decomposition and bactericidal effect. Langmuir 19(8): 3428-3431.

34. Hu C, Guo J, Qu J, Hu X (2007) Efficient destruction of bateria with $\mathrm{Ti}(\mathrm{IV})$ and antibacterial ions in co-substituted hydroxyapatite films. Appl Catal B 73: 345.

35. Li Y, Ho J, Ooi CP (2010) Antibacterial efficacy and cytotoxicity studies of copper (II) and titanium (IV) substituted hydroxyapatite nanoparticles. Materials Science \& Engineering C-Materials for Biological Applications 30: 1137.

36. Beattie JH, Avenell A (1992) Trace element nutrition and bone metabolism. Nutr Res Rev 5(1): 167-188.

37. Wang X, Ito A, Sogo Y, Li X, Oyane A (2010) Zinc-containing apatite layers on external fixation rods promoting cell activity. Acta Biomater 6(3): 962-968.

38. Miao S, Lin N, Cheng K, Yang D, Huang X, et al. (2011) Zn-Releasing FHA Coating and Its Enhanced Osseointegration Ability. J Am Ceram Soc 94: 255.

39. Mayer I, Jacobsohn O, Niazov T, Werckmann J, Iliescu M, et al. (2003) Manganese in precipitated hydroxyapatites. Eur J Inorg Chem 2003: 1445 .

40. Li Y, Widodo J, Lim S, Ooi CP (2012) Synthesis and cytocompatibility of manganese (II) and iron (III) substituted hydroxyapatite nanoparticles. J MATER SCI 47(2): 754-763.

41. Chane-Ching JY, Lebugle A, Rousselot I, Pourpoint A, Pellé F (2007) Colloidal synthesis and characterization of monocrystalline apatite nanophosphors. J Mater Chem 17: 2904.

42. Li Y, Ooi CP, Cheang PHN, Khor KA (2009) Synthesis and Characterization of Neodymium(III) and Gadolinium(III)-Substituted Hydroxyapatite as Biomaterials. Int J Appl Ceram Tech 6: 501.

43. Nakahira A, Nakamura S, Horimoto M (2007) Synthesis of modified hydroxyapatite (HAP) substituted with Fe ion for DDS application. IEEE Transactions on Magnetics 43: 2465.

44. Wu HC, Wang TW, Sun JS, Wang WH, Lin FH (2007) A novel biomagnetic nanoparticle based on hydroxyapatite. Nanotechnology 18: 165601.

45. Low HR, Phonthammachai N, Maignan A, Stewart GA, Bastow TJ, et al. (2008) The crystal chemistry of ferric oxyhydroxyapatite. Inorg Chem 47: 11774-11782. 
Your next submission with Juniper Publishers will reach you the below assets

- Quality Editorial service

- Swift Peer Review

- Reprints availability

- E-prints Service

- Manuscript Podcast for convenient understanding

- Global attainment for your research

- Manuscript accessibility in different formats

( Pdf, E-pub, Full Text, Audio)

- Unceasing customer service

Track the below URL for one-step submission https://juniperpublishers.com/online-submission.php 